\title{
International Concerns Regarding IUU Fishing
}

Successive FAO reports have demonstrated the serious state of decline of most commercially harvested fish stocks. ${ }^{23}$ In this context, IUU fishing has been identified as 'one of the most severe problems affecting world fisheries' 24 and as the 'main obstacle in achieving sustainable fisheries in both areas under national jurisdiction and the high seas'. ${ }^{25} \mathrm{~A}$ study by the Marine Resource Assessment Group Ltd (MRAG) in 2006 estimated that the total loss to IUU fishing in Guinea, Liberia, Sierra Leone, Angola, Namibia, Mozambique, Kenya, Somalia, Seychelles and Papua New Guinea amounted to US\$372 million, representing 19 per cent of the combined total value of their catches and 23 per cent of their declared value. ${ }^{26}$ A follow-up study in April 2008 by MRAG and the University of British Columbia Fisheries Centre estimated that the global losses from illegal fishing in 17 FAO statistical areas is between US $\$ 10$ billion and US $\$ 23$ billion annually, representing about 11.06 million to 25.91 million tonnes of fish. ${ }^{27}$ Apart from its economic and environmental repercussions, IUU fishing has also been equated to 'stealing food from some of the poorest of the world'28 and is known to cause the displacement of legitimate fishing communities. ${ }^{29}$

Several international efforts have been made through the FAO, the UN General Assembly and RFMOs to combat IUU fishing. The principal international instrument is the International Plan of Action to Prevent, Deter, and Eliminate Illegal, Unreported and Unregulated Fishing (IPOA-IUU), adopted under the auspices of the FAO in 2002. The IPOA-IUU is a comprehensive 'toolbox', providing a full range of measures that can be used by flag states, port states, coastal states and market states to combat IUU fishing within their jurisdiction and on the high seas. ${ }^{30}$ These measures include:

- Implementation of fishing vessel registration and licensing systems;

- Maintenance of records of fishing vessels;

- The implementation of monitoring, control and surveillance (MCS) measures;

- Port enforcement actions;

- Catch documentation schemes;

- Trade restrictions.

The suite of measures that cuts across the responsibilities of flag, coastal, port and market states is categorised under 'all state responsibilities'. These responsibilities relate to:

- The implementation of international instruments; 
- Development of national plans of action;

- Co-operation among states;

- Application of sanctions;

- Adoption of measures against IUU fishing by vessels without nationality and vessels flying the flags of non-cooperating members of RFMOs.

The measures provided for by the IPOA-IUU supplement provisions in other fisheriesrelated international instruments such as the 1982 United Nations Convention on the Law of the Sea (LOSC), the 1995 UN Fish Stocks Agreement, the FAO Compliance Agreement and the FAO Code of Conduct for Responsible Fisheries.

A number of RFMOs have also taken up the global fight against IUU fishing. Several of them, whose membership includes ACP states, ${ }^{31}$ have measures against IUU fishing in place. The relevant RFMOs include:

- The Commission for the Conservation of Southern Bluefin Tuna (CCSBT) ${ }^{32}$

- The Northwest Atlantic Fisheries Organisation (NAFO) ${ }^{33}$

- The Northeast Atlantic Fisheries Commission (NEAFC) $)^{34}$

- The Commission for the Conservation of Antarctic Marine Living Resources $(\text { CCAMLR })^{35}$

- The Indian Ocean Tuna Commission (IOTC) $)^{36}$

- The Inter-American Tropical Tuna Commission (IATTC) $)^{37}$

- The Western and Central Pacific Fisheries Commission (WCPFC) ${ }^{38}$

- The International Commission for the Conservation of Atlantic Tunas (ICCAT). ${ }^{39}$

The IUU fishing measures adopted by these RFMOs include the establishment of IUU vessel lists, records of fishing vessels, vessel monitoring systems, transhipment regulations, observer programmes, boarding and inspection procedures, port inspection schemes, trade documentation schemes and trade-related measures such as prohibition of fish landings from IUU vessels. RFMOs such as ICCAT, NEAFC, NAFO, IATTC, IOTC, CCAMLR and WCPFC have all created IUU vessel lists for vessels flying the flags of non-contracting parties, as well as contracting and co-operating non-contracting parties. ${ }^{40}$

At the regional level outside the RFMO framework, there is now a growing trend towards adoption of regional plans of action to combat IUU fishing with significant mirroring of many of the requirements under the international instruments noted above. Thus the EC and the Lake Victoria Fisheries Organisation have adopted regional plans of action to prevent, deter and eliminate IUU fishing. ${ }^{41}$ Similarly, in the Asia-Pacific region, the south-east Asian countries have adopted a regional plan of action to promote 
responsible fisheries and combat IUU fishing. ${ }^{42}$ More recently, the Southern African Development Community (SADC) adopted a statement of commitment to eradicate IUU fishing. ${ }^{43}$

At national level, some states have incorporated IUU control provisions in national law. Notable examples include New Zealand ${ }^{44}$ Australia ${ }^{45}$ and the USA..${ }^{46}$ For example, new amendments to the US Magnuson-Stevens Fishery Conservation and Management Reauthorisation Act authorise denial of port access and prohibition of the imports of fishery products from offending countries. ${ }^{47}$ 